
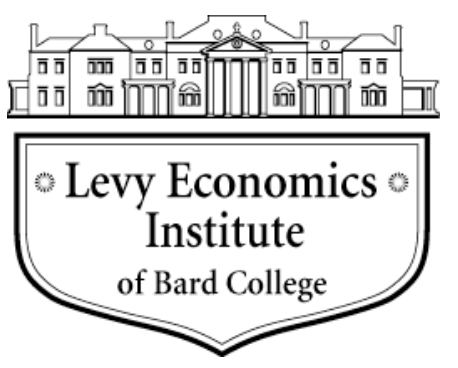

Working Paper No. 620

\title{
Measuring Poverty Using Both Income and Wealth: An Empirical Comparison of Multidimensional Approaches Using Data for the U.S. and Spain
}

by

Francisco Azpitarte ${ }^{1}$

London School of Economics and Political Science

September 2010

\footnotetext{
${ }^{1}$ Correspondence: Francisco Azpitarte, STICERD-London School of Economics and Political Science, Houghton Street, London WC2A 2AE, UK (F.Azpitarte@1se.ac.uk). I wish to acknowledge financial support from the Pedro Barrié de la Maza Foundation. This paper is part of the work I carried out as part of a postdoctoral research fellowship at LSE that was funded by the foundation.
}

The Levy Economics Institute Working Paper Collection presents research in progress by Levy Institute scholars and conference participants. The purpose of the series is to disseminate ideas to and elicit comments from academics and professionals.

Levy Economics Institute of Bard College, founded in 1986, is a nonprofit, nonpartisan, independently funded research organization devoted to public service. Through scholarship and economic research it generates viable, effective public policy responses to important economic problems that profoundly affect the quality of life in the United States and abroad.

Levy Economics Institute

P.O. Box 5000

Annandale-on-Hudson, NY 12504-5000

http://www.levyinstitute.org

Copyright (C) Levy Economics Institute 2010 All rights reserved 


\begin{abstract}
This paper presents a comparative analysis of the approaches to poverty based on income and wealth that have been proposed in the literature. Two types of approaches are considered: those that look at income and wealth separately when defining the poverty frontier, and those in which these two dimensions are integrated into a single index of welfare. We illustrate the implications of these approaches on the structure of poverty using data for two industrialized countries-for example, the United States and Spain. We find that the incidence of poverty in these two countries varies significantly depending on the poverty definition adopted. Despite this variation, our results suggest that the poverty problem is robust to changes in the way poverty is measured. Regarding the identification of the poor, there is a high level of misclassification between the poverty indices: for most of the pairwise comparisons, the proportion of households that are misclassified is above 50 percent. Interestingly, the rate of misclassification in the United States is significantly lower than in Spain. We argue that the higher correlation between income and wealth in the United States contributes to explaining the greater overlap between poverty indices in this country.
\end{abstract}

Keywords: Wealth; Income; Multidimensional Poverty

JEL Classifications: D14, D31 


\section{Introduction}

There is a broad consensus among economists about the consideration of poverty as a multidimensional phenomenon. To date, however, most official statistics on poverty computed in rich and poor countries are based solely on household income. Numerous contributions have recently remarked the necessity to supplement standard income poverty measures with information on other households' attributes in order to obtain a more comprehensive measure of household welfare (Chakravarty and Silber 2007, Chakravarty et al. 2005, Bourguignon and Chakravarty 2003). Among the possible determinants of welfare, the contribution of wealth to households' well-being has received an increasing attention during the last years. Beyond the direct income flows provided by assets, wealth holdings are central to the measurement of vulnerability of households in times of economic crisis as they will determine the extent to which families can smooth consumption in periods of low income. Empirical evidence from income based poverty studies suggests that there exists a large low income turnover, with a significant number of households falling below the income threshold and experiencing low income spells (Jarvis and Jenkins, 1998). It is then clear that the limited information on income flows may not be fully informative about the capacity that families have for sustaining a minimum standard of living during low income periods. Therefore, the joint analysis of income and wealth will clearly contribute to improve our knowledge about households' well-being, allowing us to study the correspondence between households' current income and their vulnerability to income shocks, measured by the availability of wealth holdings for maintaining consumption during income-poverty spells.

An important issue one needs to address when performing multidimensional poverty analysis is how to integrate the various dimensions of welfare. In the case of income and wealth, two alternative approaches have been proposed in the literature. In the first one, suggested by Radner and Vaughan (1987), income and wealth are treated independently so the poor population is identified assuming a joint threshold for income and wealth. Alternatively, the second approach proposed by Weisbrod and Hansen (1968) integrates income and wealth into a single index of welfare using the annuity method to convert household wealth into an income flow. Thus, household's economic welfare is given by the sum of its current income plus the lifetime annuity value of its current wealth, such that every household whose income-wealth value is under the income-poverty threshold is identified as poor. Importantly, these two approaches differ regarding relevant methodological issues that may have important implications on the structure of poverty. Indeed, while the first method does not consider the possibility of trade off between meagre and non- 
meagre attributes when determining the poverty status, the annuity approach allows for the possibility of such a type of compensation between income and wealth. Furthermore, the different role of age in defining the poverty status in the two approaches may have important consequences on the age distribution of the poor. Thus, whereas information on age is irrelevant for the definition of the poor in the method proposed by Radner and Vaughan (1987), the classification of the poor using the income-wealth measure importantly depends on the age of the economic unit, as the value of the annuity from wealth varies with the life expectancy of the unit.

Despite of the important differences between the two multidimensional approaches, yet no comparative analysis of these two approaches has been provided in the literature. The main purpose of this paper is to fill this gap. We investigate the consequences of the alternative poverty definitions based on income and wealth looking at how the incidence and the characterization of poverty vary depending on the way poverty is measured. In particular, we are especially interested in to assess to what extent the alternative approaches identify the same households as poor. We believe this is highly relevant question for social policy design as many welfare programs in developed countries are considering information on both income and wealth to determine eligibility for social benefits. Interestingly, we find that the degree of misclassification of the households identified as poor is above 50 percent for most of the pairwise comparisons between poverty definitions.

We illustrate the differences between the two poverty approaches using data for two industrialized countries such as the U.S. and Spain. We argue the comparison of these two countries is relevant for several reasons. First, the U.S. and Spain present important differences that may condition the relationship between household income and wealth. Indeed, Bover (2010) shows that Spain and the U.S. exhibit important differences in the demographic structure and the household formation process, with Spain showing a larger share of young people living with their parents, which has important effects on the saving behavior and the stock of wealth accumulated over the life cycle. Further, the U.S. and Spain are both characterized by a welfare model typically catalogued as rather weak compared to that found in Nordic countries (Esping-Andersen et al., 2002). The measurement of vulnerability using wealth holdings is especially interesting in this context given the greater importance of assets as insurance mechanism in a low social protection situation. Lastly, the generosity of the tax and benefit systems and the regulation of the labor market differs significantly in these two countries, with the U.S. usually seen as the prototype of a liberal market economy, whereas Spain presents a highly regulated labor 
market with a larger unemployment protection from the welfare state.

The paper is organized as follows. In Section 2, we review the multidimensional approaches to poverty based on income and wealth that have been proposed in the literature. Section 3 is the core section of the paper. It includes the description of the data sources and methods used in the analysis. Also in this section, we present the main results of our multidimensional poverty analysis for the U.S. and Spain. We close this section with a discussion on the misclassification of poor households by the different poverty definitions. Finally, in Section 4 we summarize the main conclusions of our analysis.

\section{Theoretical Background}

Welfare indicators based on income and wealth allow for a better identification of those who are in greater need than measures based solely on income as they are more informative about the real financial situation of the households. However, the measurement of poverty based on income and wealth raises two important issues that need to be addressed. First, one must decide on the particular assumptions on how the two dimensions interact for determining the households' economic welfare. Secondly, a criterion needs to be defined in order to identify who is poor. Importantly, the two approaches to poverty based on income and wealth that have been proposed in the literature differ significantly in these two aspects. Thus, the first approach, suggested by Radner and Vaughan (1987) and Wolff (1990), treats the two dimensions independently and identifies the poor assuming a joint threshold for income and wealth. More formally, let $Y_{t}$ and $W_{t}$ denote the value of household income and household wealth in period $t$, respectively. Further, let $Z_{y}$ and $Z_{w}$ be the income and wealth poverty thresholds reflecting the amount of income and wealth required to meet some socially acceptable minimal standard of living, whose definitions will be discussed in the next section. Using this framework, these authors consider two alternative definitions of poverty. The first one, which we call the union criterion, identifies as poor any household who has an insufficiency in either income and wealth. Thus, the set of households identified as poor is given by

$$
\begin{aligned}
& \mu_{U}(i)=1 \text { if } Y_{t} \leq Z_{y} \text { or } W_{t} \leq Z_{w} \\
& \mu_{U}(i)=0 \text { otherwise }
\end{aligned}
$$

where $\mu_{U}(i)$ is a poverty indicator function taking value 1 for those households identified as poor according to the union definition, and zero otherwise. The second poverty criterion 
within this approach corresponds to the intersection definition of poverty, according to which a household is classified as poor if it faces an inadequacy in both income and wealth. Then, the poverty indicator function $\mu_{I}(i)$ of household $i$ in this case is defined as

$$
\begin{aligned}
& \mu_{I}(i)=1 \text { if } Y_{t} \leq Z_{y} \text { and } W_{t} \leq Z_{w} \\
& \mu_{I}(i)=0 \text { otherwise. }
\end{aligned}
$$

Figure 1 shows the difference between the poverty frontiers implied by the two poverty definitions. While the union poverty index considers as poor every pair $(Y, W)$ included in the L-shaped region determined by $Z_{y}$ and $Z_{w}$, the intersection criterion considers a household to be in poverty only if it lies within the rectangle determined by the two poverty lines. Importantly, in both the union and intersection definitions the poverty status is determined by looking separately at the shortfall from the threshold on each of the dimensions. In contrast, the second approach to poverty allows for the possibility of interaction between income and wealth as these two variables are combined into a single index of welfare. In particular, the approach proposed by Weisbrod and Hansen (1968) defines the economic position of a household, $A Y_{t}$, as the sum of its current income net of yield from wealth and the annual income flow should the household perceive if its current wealth were used to buy an annuity. Thus, $A Y_{t}$, can be expressed as follows

$$
A Y_{t}=Y_{t}-\tilde{r}_{t} W_{t}+\frac{r_{t}}{1-\left(1+r_{t}\right)^{-n}} W_{t}
$$

where $\tilde{r}_{t}$ is the household specific rate of return from wealth that would be sacrificed in the case the annuity were bought, ${ }^{1}$ and the last term in the right hand side measures the annuity income flow defined as a function of the current interest rate, $r_{t}$, the length of the annuity, $n$, and the amount of wealth, $W_{t} .^{2}$ Regarding the length of the annuity, two values have been used in the literature. First, following Weisbrod and Hansen (1968), the value of $n$ is set equal to the economic unit's life expectancy which implies that the household's economic position will depend on the age of its members. Thus, the shorter the expected lifetime the larger the annuity flow from wealth, which means that, other

\footnotetext{
${ }^{1}$ The value of $\tilde{r}_{t}$ will depend on the composition of the household asset portfolio. Notice that the return from income-yielding assets must be deducted from the income measure in order to avoid the double counting of wealth.

${ }^{2}$ The term $\frac{r_{t}}{1-\left(1+r_{t}\right)^{-n}}$ represents the value of an $n$ period annuity whose present value is one unit of money. We follow Weisbrod and Hansen (1968) and we assume that all wealth is annuitized and no bequest are left. However, as the authors recognize, the consideration of bequests only requires a simple modification in equation (3).
} 
things being equal, old households will have a better economic status than younger units simply because of their shorter life expectancy. ${ }^{3}$ Alternatively, wealth could be annuitized entirely in one period, in which case (3) can be rewritten as

$$
A Y_{t}=Y_{t}-\tilde{r}_{t} W_{t}+\left(1+r_{t}\right) W_{t} .
$$

With regards the measurement of poverty, poverty analysis based on the annuity measure define the extent of poverty using the existing income poverty threshold (Zagorsky 2006, Short and Ruggles 2006, Van den Bosch 1998, Weisbrod and Hansen 1968). Thus, according to these authors a household will be identified as poor whenever the value of the income-wealth measure is not enough to meet minimum income needs, that is,

$$
A Y_{t} \leq Z_{y},
$$

where $Z_{y}$ is the unidimensional income poverty line. Then, the set of households identified as poor in the case wealth is assumed to be annuitized over households' expected lifetime is given by

$$
\begin{aligned}
& \mu_{n=l e}(i)=1 \text { if } Y_{t}-\tilde{r}_{t}^{i} W_{t}+\frac{r_{t}}{1-\left(1+r_{t}\right)^{-l e_{i}}} W_{t} \leq Z_{y} \\
& \mu_{n=l e}(i)=0 \text { otherwise }
\end{aligned}
$$

where $l e_{i}$ measures the life expectancy of household $i$. Similarly, when the length of the annuity from wealth is set equal to one period, the poverty indicator function is defined as follows

$$
\begin{aligned}
& \mu_{n=1}(i)=1 \text { if } Y_{t}-\tilde{r}_{t}^{i} W_{t}+\left(1+r_{t}\right) W_{t} \leq Z_{y} \\
& \mu_{n=1}(i)=0 \text { otherwise. }
\end{aligned}
$$

The divergence between the annuity based and the union and intersection poverty indices is clear from Figure 1. The poverty sets determined by the annuity indices depend on the values of $Z_{y}$ and $r_{t}$, as well as, on household specific parameters such as $\tilde{r}_{t}^{i}$ and $l e_{i}$. An increase in $Z_{y}, l e_{i}$, or $\tilde{r}_{t}^{i}$ will shift upwards the poverty frontiers, whereas larger values of $r_{t}$ will make the curves pivot to the left. Importantly, while in (7) household life expectancy

\footnotetext{
${ }^{3}$ In particular, Weisbrod and Hansen (1968) and the subsequent papers that used the annuity measure, identify the age of household with the age of the head. This is precisely the approach we will follow in this paper.
} 
is not relevant for defining the poverty status, the classification of the poor according to (6) depends on the age of the household. This, in turn, may have different implications on the age structure of poverty. In fact, since older persons have a shorter life expectancy and therefore a higher annuity value for a given level of wealth, we expect a younger population in poverty when the value of the annuity depends on the household expected lifetime than in the case where all households annuitize their wealth in one period. Interestingly, as Figure 1 shows, the annuity poverty indices represent an intermediate approach to poverty. Indeed, differently to the intersection definition of poverty it is possible to find households deprived in both income and wealth who are not identified as poor by the annuity criteria. Further, in contrast with the union approach and due to the possibility of compensation between attributes, a household who is deprived in one dimension can be classified as non-poor if the value of the non-meagre attribute is sufficiently high to lie to the right of the annuity poverty frontier.

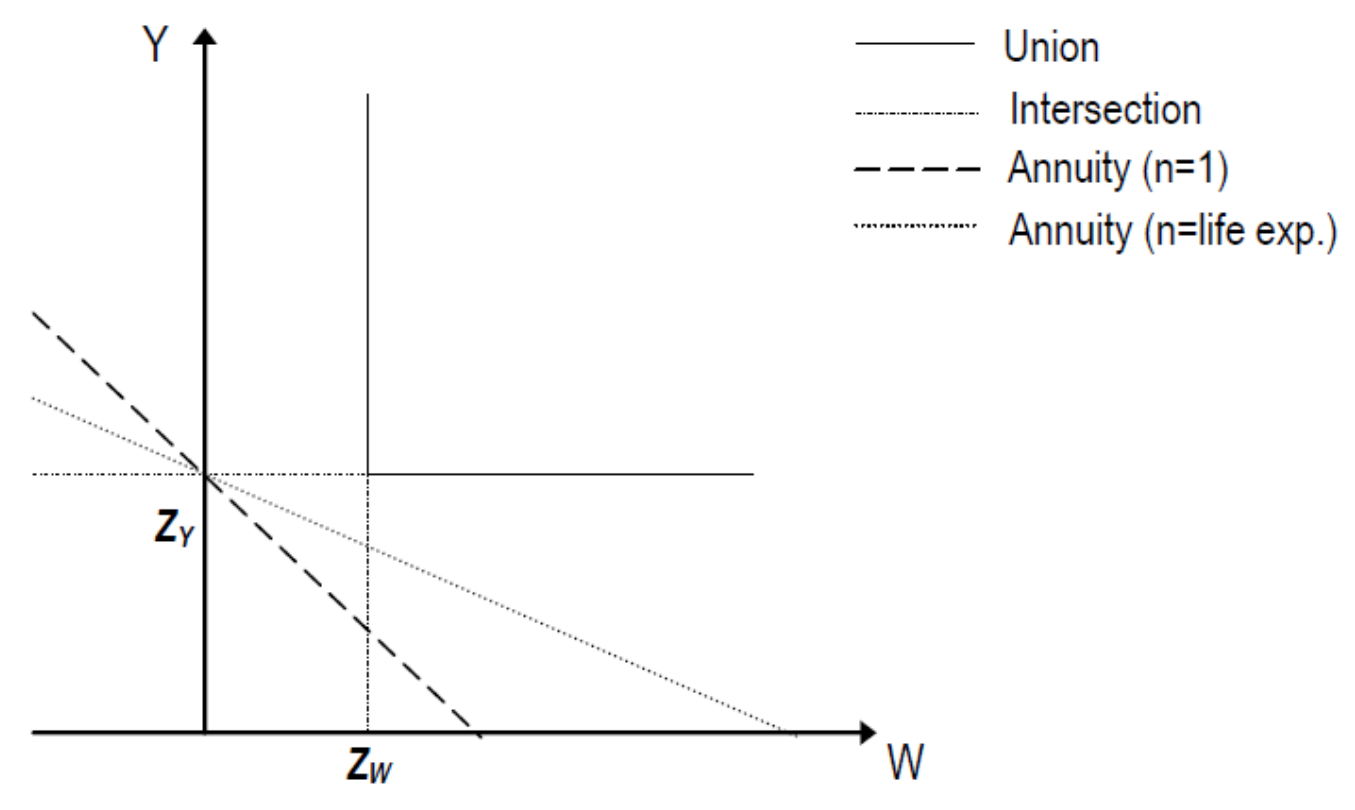

Figure 1. Union, Intersection, and Annuity Poverty Indices 


\section{An illustration using data for the US and Spain}

\subsection{Data Sources and Methods}

We rely on data from two highly comparable wealth surveys in the U.S. and Spain. In particular, the data for the U.S. is from the 2001 Survey of Consumer Finances (SCF), ${ }^{4}$ whereas for Spain we use the information in the first wave of the Spanish Survey of Household Finances (Encuesta Financiera de las Familias, EFF) conducted in 2002. ${ }^{5}$ Both the SCF and the EFF are aimed at providing detailed information about the assets and liabilities held by households, as well as data on employment, income, and other demographic characteristics of the households in the U.S. and Spain, respectively. Thus, the 2001 SCF provides all this information for a sample with more than 4,000 households, while the first wave of the EFF includes a sample with more than 5,000 households.

Importantly, the EFF and the SCF share relevant methodology features that make them especially suitable for comparative analysis. ${ }^{6}$ Indeed, an important characteristic of these two samples is the over-sampling of wealthy households. ${ }^{7}$ As Davies and Shorrocks (2000) suggest, this is a necessary condition in order to obtain an accurate picture of aggregate wealth, given that an important share of total assets belongs to the richest households. Another common feature in the EFF and in the SCF is that both surveys use the same imputation method to provide complete information on households' income and wealth holdings even if a household fails to respond to the complete questionnaire. ${ }^{8}$

Data on income and wealth provided in the SCF and the EFF is rather homogeneous, which allows a high degree of comparability between the U.S. and Spain. ${ }^{9}$ With regard to the data on income, the variable we use in the analysis is the annual household gross

\footnotetext{
${ }^{4}$ We use the data from the 2001 SCF included in the Luxembourg Wealth Study (LWS) database. The LWS is an international project launched in 2003, whose primary goal is to harmonize existing microdata on wealth. At present, Austria, Canada, Cyprus, Finland, Germany, Italy, Norway, Sweden, United States and United Kingdom are contributing with their national data sets. A complete description of the LWS database can be found in http://www.lisproject.org.

${ }^{5}$ For a detailed description of the methodology used in the first wave of the EFF, see Bover (2004).

${ }^{6}$ Indeed, the EFF was constructed following the model of the SCF (Bover, 2004).

${ }^{7}$ Over-sampling in the EFF is based on the individual information of the Spanish wealth tax (Impuesto sobre el Patrimonio), while in the SCF it is based on a supplementary high-income sample drawn from income tax records. For more information on these two procedures, see Bover (2004) and Kennickell (2008).

${ }^{8}$ The imputation method is the Federal Reserve Imputation Technique Zeta (Fritz). This is a stochastic method with a sequential and iterative structure. For more details, see Kennickell (1998 and 2000).

${ }^{9} \mathrm{~A}$ complete description of the information included in the SCF and the EFF and the income and wealth variables used in the analysis can be found in the appendix.
} 
income (before taxes and contributions to the Social Security System). ${ }^{10}$ This variable is the sum of wages and salaries, self-employment earnings, capital income, unemployment benefits, private and public retirement pensions, and other transfers received by any household member. Importantly, in order to avoid the double counting of the income produced by assets an adjusted income measure net of the yield from wealth is considered when computing the annuity income flow. Thus, cash property income in the form of rent, interest, dividends, and business profits is excluded from the gross income variable when imputing the annuity from wealth. ${ }^{11}$

In the case of wealth, the EFF and the SCF, provide detailed information for a wide range of tangible and financial assets as well as the household's outstanding debts at the moment of the interview, which allows us to construct the two measures of wealth we consider in our analysis. The first of these measures is net worth, and it is aimed to reflect the households' store of value that can be used to sustain the household for some period of time. Concretely, this measure is defined as the total value of fungible real and financial assets minus the current value of debts. Real assets include the gross value of owner-occupied housing, other real estate, and business equities related to selfemployment, and collectibles. ${ }^{12}$ Financial assets include the current value of transaction and saving accounts, total bonds, stocks, mutual and investment funds, private pension schemes, life insurance, and other financial assets. Finally, the value of total debt is the sum of principal residence debt, other real estate debt, vehicle and educational loans, and other debts. ${ }^{13}$. Our second measure of wealth represents a more liquid wealth concept as it excludes the housing wealth component which is less likely to be liquidated during bad times. Thus, non-housing wealth (NHW) is equivalent to net worth minus the net value of the principal residence.

\footnotetext{
${ }^{10}$ In both surveys households are asked to report the income perceived during the year previous to the survey. Thus, income data for Spain correspond to 2001, while for the U.S. it measures the income households received in 2000. We decided to use a gross measure of income because the Spanish survey does not include any income measure net of taxes and contributions to the Social Security System.

${ }^{11}$ This is the income variable we denoted by $\tilde{r}_{t}^{i} W_{t}$ in the theoretical discussion, and it amounts to the value of income that would be sacrificed in the case the annuity were bought.

${ }^{12}$ This category includes the value of gold, silver, antiques, stamp collections, and other collectibles in the household.

${ }^{13}$ This category includes the value of installment debt, other loans from financial institutions, and informal debt. Notice that our net worth measures includes debts on consumer durables despite of not including the value on these assets. As Wolff (1998) rightly pointed out, loans for the acquisition of consumer durables usually exceed their resale value shortly after the purchase.
} 
The unit of analysis we use in this paper is the household. In both surveys, a household is defined as including all individuals living together in the same dwelling, but additional requirements are considered in each survey. In the case of Spain, sharing expenses is a condition to form a household, while in the U.S., financial interdependence with the economically dominant person or couple is required. Further, as it is usual in regular income poverty analysis, we convert income to equivalent income taking into account the differences in needs across households due to the economies of scale in consumption. In the case of wealth, since we are interested in the ability of families to overcome times of economic crisis using accumulated wealth holdings, we also consider differences in needs across households when measuring wealth. ${ }^{14}$ Thus, we compute the equivalent values of both income and wealth variables using a consistent single parameter scale with a square root of household size scale factor. In particular, adjusted variables are equal to unadjusted variables divided by household size raised to an exponential value equal to 0.5. ${ }^{15}$. Data on household life expectancy required to compute the annuity from wealth were collected from the U.S. National Centre for Health Statistics, whereas information for Spain comes from the figures provided by the Spanish Statistical Office (Instituto Nacional de Estadistica, INE).

As regards the poverty thresholds, the official methods used to identify income-poor households in Spain and the U.S. differ regarding various methodological issues. ${ }^{16}$ In particular, income-poverty measurement in the U.S. is based on a set of absolute incomepoverty thresholds aimed to reflect the basic cost of living in this country, while in Spain, as in other E.U. countries, a relative notion of income-poverty is adopted in the so called the "Laeken" indicators of poverty, which are computed using an income-poverty line set equal to a percentage of the median income. For the sake of comparability, in this paper we will follow a relative approach to measuring income-poverty in Spain and the U.S. In order to check for the sensitivity of results to a particular choice of the income threshold, $Z_{y}$, we use three different income thresholds that correspond to the 40,50 , and 60 percent

\footnotetext{
${ }^{14}$ In contrast with income distribution analysis, in the case of wealth there is no standard approach to account for different needs across households. In a recent discussion on the use of equivalence scales in wealth distribution analysis, Sierminska and Smeeding (2005) show that measures of wealth inequality are sensitive to equivalence scales, decreasing when higher economics of scale are assumed.

${ }^{15}$ This is a particular case of the family of equivalence scales proposed by Buhmann et al.(1988) widely used in regular inequality and poverty analysis, where household needs are equal to $S^{\theta}$, where $S$ is the size of the household and $\theta$ is the elasticity of the scale rate, which in our case is set equal to 0.5 .

${ }^{16}$ For an excellent discussion of the official methods used to measure income-poverty in the U.S. and in E.U. countries, see Notten and Neubourg (2007).
} 
of the median income. ${ }^{17}$ For the measurement of asset-poverty, following Haveman and Wolff (2005) and Caner and Wolff (2004) we define the wealth-poverty threshold, $Z_{w}$, as a function of the relative annual income poverty line. ${ }^{18}$ More concretely, we propose two wealth-poverty lines that result from dividing the annual income threshold by 4 and 2 , where the idea is to check if the household could support itself with wealth holdings at the income-poverty line for three and six months, respectively. ${ }^{19}$ Fortunately, the conclusions of our analysis are not sensible to the particular choice of the income and wealth poverty thresholds.

\subsection{Results}

\subsubsection{The joint distribution of income and wealth}

We start our analysis looking at the distribution of income and wealth in Spain and the US. To this purpose, Table 1 presents some descriptive statistics of the two distributions, as well as information on the association between these variables in the two countries. According to the figures on this table, wealth variables display more population mass at extreme values than the distribution of income in both countries. However, this feature is more important in the U.S. than in Spain. In fact, the percentage of net worth held by the richest 5 and 1 percent households in the U.S. is about twice that of their Spanish counterfacts. On the contrary, the proportion of households with zero or negative wealth holdings is larger in the U.S. than in Spain whatever the wealth measure considered. Indeed, the proportion of Spanish households that do not hold any positive amount of net worth or non-housing wealth is about 2 and 11 percent, respectively, while in the case of the U.S. these percentages are above 17 and 26 percent.

\footnotetext{
${ }^{17}$ Jesuit and Smeeding (2002) show that the U.S. absolute poverty line is close to the 40 percent threshold.

${ }^{18}$ This option differs from that adopted by Hubbard et al. (1995) to analyze the relationship between asset-based, means-tested social welfare programs and the number of low-wealth households in the U.S. In particular, these authors use a household-specific wealth threshold that depends on household income, such that, every household with net-worth less than their annual current income is identified as assetpoor. An important drawback of this methodology is that it is possible that households with low wealth holdings may not be considered as asset-poor if they also have low income, while households with a large amount of wealth may be identified as wealth-poor simply because their wealth is relatively low compared with their income.

${ }^{19}$ This definition differs from that in Haveman and Wolff (2005) and Caner and Wolff (2004) in that they use the family-size conditioned poverty thresholds proposed by the U.S. National Academy of Science Panel instead of the relative income poverty thresholds considered here.
} 
With regard to the association between income and wealth, the results shown in Table 1 reveal a positive correlation between the two dimensions in both countries. However, the association between these two variables in the U.S. is markedly larger than in Spain, as suggested by the difference in the values of the correlation coefficient ( 0.5 versus 0.15$).{ }^{20}$ This difference is mainly attributable to the non-housing component of wealth, since the correlation between this component and income in the U.S. is more than three times that in Spain, whereas the association between income and housing wealth is similar in the two countries. The larger association between income and wealth found in the U.S. is confirmed by the lower re-ranking between the two distributions in the U.S. compared with Spain, as shown by the transition matrices based on the quintile distributions of income and net worth presented at the bottom of Table 1. Information in each matrix is synthesized with the diagonal index $M(P)$ proposed by Shorrocks (1978) (0.89 for Spain, 0.83 for the U.S.). The figures indicate a larger upward mobility in Spain, where about 22 and 24 percent of the households in the bottom quintile of income and wealth, respectively, are in the fourth or fifth quintile of the other dimension when there is re-ranking, compared with 14 percent in the U.S. Consistent with this result, we find that the U.S. presents a greater correspondence at the bottom and the top of the distributions: 44 and 51 percent of U.S. households in the bottom and top quartile of income, respectively, remain in the same quartile of net worth after re-ranking, compared with 32 and 44 percent in Spain. ${ }^{21}$ Jäntti et al. (2008) described the quartile distribution of income and wealth in the U.S., Canada, Italy, and Sweden using information in the LWS database, and they found that within this group of countries, the U.S. has the highest concentration of population in the bottom and the top income-wealth quartile groups. Our figures for Spain are similar to those reported by these authors for Italy and Canada, while their results for Sweden show that the correspondence at the bottom of the distributions in this country is lower than in Spain, given that less than 30 percent of Swedish households at the bottom quartile of income are also in the same quartile of wealth.

\footnotetext{
${ }^{20}$ This result for the U.S. is similar to that found for this country by Budria et al. (2002). These authors report that the correlation coefficient between income and wealth in the U.S. in 1998 was equal to 0.6 .

${ }^{21}$ Our results for the U.S. are similar to those found by Radner and Vaughan (1987). These authors computed a transition matrix for U.S. using data for 1979, and they reported a value of the mobility index equal to 0.85 .
} 
Table 1

The distribution of income and wealth in the U.S. and Spain

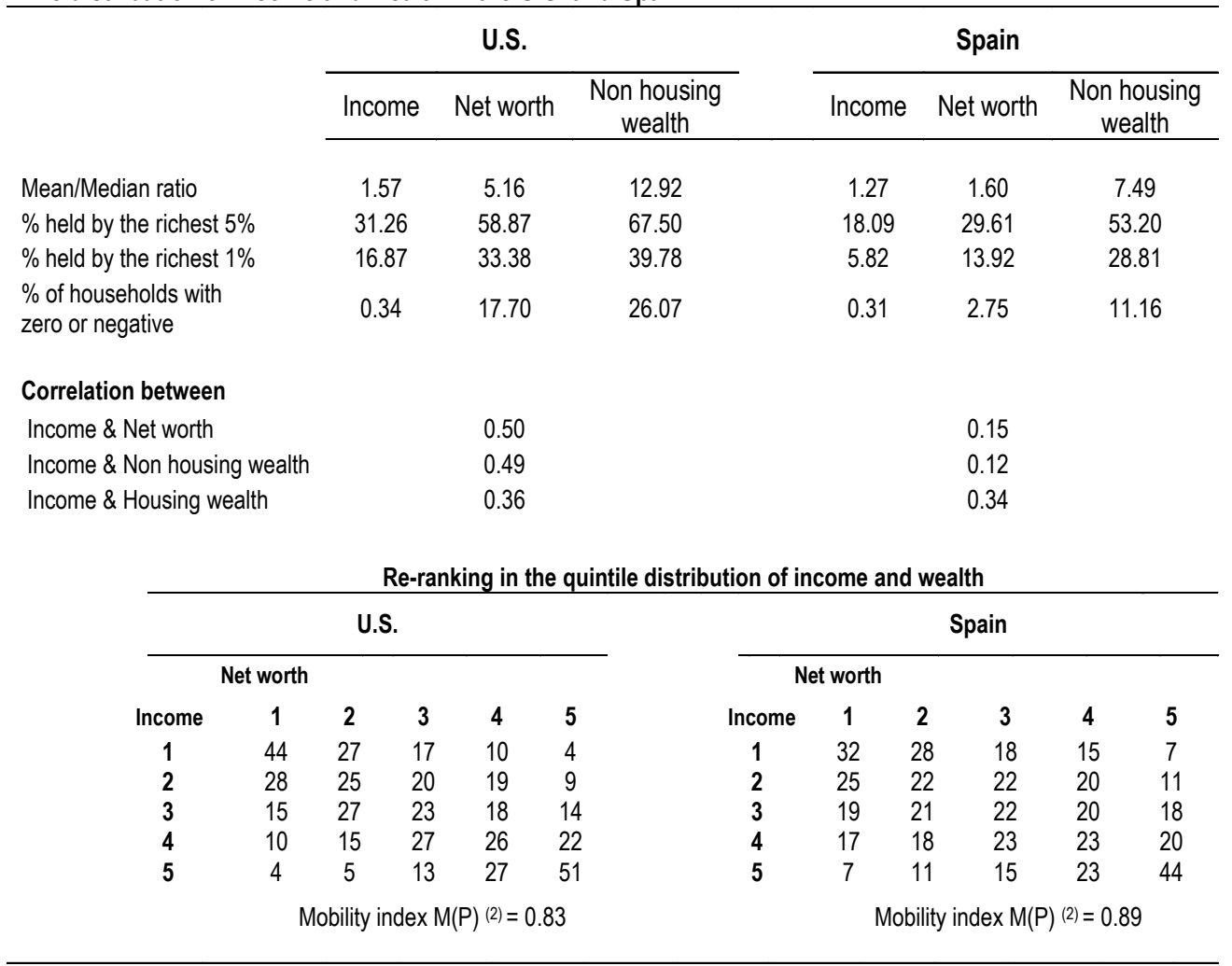

Source: Author's calculations using the EFF 2002 and data from the SCF 2001 included in the LWS database.

(1) For the definition of income, net worth, housing and non-housing wealth see Section 3.1. Income and wealth variables are adjusted using the square root equivalence scale according to which each variable is divided by the square root of the household size.

(2) The diagonal index $M(P)$ is equal to $((n-\operatorname{tr}(P)) /(n-1)$, where $n$ is the number of percentiles and $\operatorname{tr}(P)$ is the trace of the transition matrix. Notice that when there is no mobility the index is equal to zero, while in the case of maximal mobility it is equal to $(\mathrm{n} /(\mathrm{n}-1))$.

\subsection{Poverty analysis using both income and wealth}

The aim of this section is to measure and characterize poverty using information on both income and wealth. To this purpose, Table 2 shows the incidence of poverty in the U.S. and Spain for the different poverty approaches. The results on this table suggest that the incidence of poverty in these countries varies importantly depending on the way poverty is defined. More concretely, we find that the proportion of households identified as poor by the union method is larger than that obtained with the intersection criterion, with the poverty figures based on the annuity measure lying between the two. Thus, for instance, in the case of income and net worth and the 50 percent income poverty threshold, the number of poor households in the U.S. and Spain ranges between 11 and 39 percent and between 3 and 24 percent, respectively, depending on the definition adopted. Interestingly, 
the size of poverty in the U.S. is larger than is Spain regardless of the particular poverty approach and the combination of poverty lines considered. In particular, the most striking difference between these two countries is found when the intersection definition is used, as the proportion of households identified as poor under this criterion in the U.S. is between 1.5 and 6 times that in Spain.

Table 2

Income and wealth poverty rates in the U.S. and Spain

(All variables in percentage)

\begin{tabular}{|c|c|c|c|c|c|c|c|c|}
\hline \multirow[b]{4}{*}{$Z_{Y}=40 \%$} & \multicolumn{4}{|c|}{ U.S. } & \multicolumn{4}{|c|}{ Spain } \\
\hline & \multicolumn{2}{|c|}{ Income \& Net worth } & \multicolumn{2}{|c|}{ Income \& NHW } & \multicolumn{2}{|c|}{ Income \& Net worth } & \multicolumn{2}{|c|}{ Income \& NHW } \\
\hline & $Z_{W}=Z_{Y} / 4$ & $Z_{w}=Z_{\gamma} / 2$ & $Z_{w}=Z_{Y} / 4$ & $Z_{w}=Z_{Y} / 2$ & $Z_{w}=Z_{\gamma} / 4$ & $Z_{w}=Z_{Y} / 2$ & $Z_{W}=Z_{Y} / 4$ & $Z_{w}=Z_{Y} / 2$ \\
\hline & & & & & & & & \\
\hline Union & 32.9 & 35.1 & 41.2 & 44.5 & 16.9 & 18.4 & 38.6 & 45.1 \\
\hline Intersection & 9.3 & 9.8 & 12.4 & 13.3 & 1.6 & 1.7 & 4.5 & 5.3 \\
\hline \multicolumn{9}{|l|}{ Annuity $n=1$} \\
\hline $3 \%$ & 12.6 & 12.6 & 16.9 & 16.9 & 2.2 & 2.2 & 7.6 & 7.6 \\
\hline $5 \%$ & 12.6 & 12.6 & 16.9 & 16.9 & 2.2 & 2.2 & 7.6 & 7.6 \\
\hline $7 \%$ & 12.6 & 12.6 & 16.9 & 16.9 & 2.2 & 2.2 & 7.6 & 7.6 \\
\hline \multicolumn{9}{|c|}{ Annuity $n=$ life exp.(3) } \\
\hline $3 \%$ & 14.3 & 14.3 & 16.9 & 16.9 & 5.7 & 5.7 & 10.8 & 10.8 \\
\hline $5 \%$ & 13.8 & 13.8 & 16.6 & 16.6 & 4.6 & 4.6 & 10.1 & 10.1 \\
\hline $7 \%$ & 13.5 & 13.5 & 16.2 & 16.2 & 4.0 & 4.0 & 9.8 & 9.8 \\
\hline \multicolumn{9}{|l|}{$Z_{Y}=50 \%$} \\
\hline Union & 36.9 & 39.4 & 44.6 & 48.1 & 23.0 & 24.2 & 43.6 & 50.2 \\
\hline Intersection & 11.8 & 12.7 & 16.0 & 17.3 & 3.1 & 3.3 & 8.3 & 10.0 \\
\hline \multicolumn{9}{|l|}{ Annuity $n=1$} \\
\hline $3 \%$ & 15.2 & 15.2 & 20.7 & 20.7 & 3.9 & 3.9 & 11.9 & 11.9 \\
\hline $5 \%$ & 15.2 & 15.2 & 20.7 & 20.7 & 3.9 & 3.9 & 11.9 & 11.9 \\
\hline $7 \%$ & 15.2 & 15.2 & 20.7 & 20.7 & 3.9 & 3.9 & 11.9 & 11.9 \\
\hline \multicolumn{9}{|c|}{ Annuity $n=l i f e$ exp.(3) } \\
\hline $3 \%$ & 18.7 & 18.7 & 21.7 & 21.7 & 10.0 & 10.0 & 17.4 & 17.4 \\
\hline $5 \%$ & 18.4 & 18.4 & 21.5 & 21.5 & 8.3 & 8.3 & 16.8 & 16.8 \\
\hline $7 \%$ & 17.7 & 17.7 & 21.3 & 21.3 & 7.3 & 7.3 & 16.3 & 16.3 \\
\hline \multicolumn{9}{|l|}{$Z_{Y}=60 \%$} \\
\hline Union & 41.2 & 43.3 & 48.4 & 51.3 & 29.6 & 30.7 & 49.0 & 55.0 \\
\hline Intersection & 14.1 & 15.8 & 19.4 & 21.1 & 4.6 & 5.0 & 12.9 & 15.3 \\
\hline \multicolumn{9}{|l|}{ Annuity $n=1$} \\
\hline $3 \%$ & 18.0 & 18.0 & 24.5 & 24.5 & 5.3 & 5.3 & 16.3 & 16.3 \\
\hline $5 \%$ & 18.0 & 18.0 & 24.5 & 24.5 & 5.3 & 5.3 & 16.3 & 16.3 \\
\hline $7 \%$ & 18.0 & 18.0 & 24.5 & 24.5 & 5.3 & 5.3 & 16.3 & 16.3 \\
\hline \multicolumn{9}{|c|}{ Annuity $n=$ life exp..$^{(3)}$} \\
\hline $3 \%$ & 23.9 & 23.9 & 27.0 & 27.0 & 14.9 & 14.9 & 24.8 & 24.8 \\
\hline $5 \%$ & 23.2 & 23.2 & 26.8 & 26.8 & 13.4 & 13.4 & 24.3 & 24.3 \\
\hline $7 \%$ & 22.9 & 22.9 & 26.5 & 26.5 & 11.6 & 11.6 & 23.6 & 23.6 \\
\hline
\end{tabular}

Source: Author's calculations using the EFF 2002 and data from the SCF 2001 included in the LWS database.

(1) For the definition of income, net worth, housing, and non-housing wealth (NHW) see Section 3.1. Income and wealth variables are adjusted using the square root equivalence scale according to which each variable is divided by the square root of the household size.

(2) Wealth poverty line, $Z_{w}$, expressed as a proportion of the income poverty threshold, $Z_{\gamma}$, where this is computed as a percentage of the median annual household equivalent income.

(3) In computing the annuity from wealth we follow the approach proposed by Weisbrod and Hansen (1968). Thus, the value of the annuity is estimated assuming wealth is annuitized over the expected remaining years of the unit's life measured as the life expectancy of the household head. For couples, it is assumed the full annuity is received while both spouses are expected to be alive, but that the surviving spouse would receive two-thirds of the full annuity over the remainder of her life. 
In order to the characterize the poor population and to identify differences in the poverty profile, Table 3 shows the incidence and distribution of the poor by households groups for the different poverty definitions. ${ }^{22}$ In addition, to further assess the impact that different socioeconomic characteristics have on the probability of being poor, we use a logit model in which the dependent variable is an poverty indicator variable that assigns a value 1 if the household is identified as poor, and zero otherwise. Table 4 shows the estimation results computed taking the household as the reference unit and using the corresponding sample weights in order to run the regressions. ${ }^{23}$ The figures reported in Tables 3 and 4 suggest that the poverty profile found within each country is very similar for the alternative approaches to poverty considered. Thus, as the results on Table 3 show, in both the U.S. and Spain the incidence of poverty is maximal among households below 35 and then it decreases with the age of the head regardless of the definition of the poor. In fact, young households headed by individuals under 35 are markedly more vulnerable to poverty than other age groups, as suggested by the value and significance of the dummy variables for these groups reported in Table 4. Interestingly, the incidence of poverty among households headed by individuals under 35 in the U.S. more than doubles that in Spain. This result may be explained by the differences in the emancipation age and the household formation process across countries (Guiliano 2007, Becker et al. 2005, Reher 1998, Fernández-Cordón, 1997). In particular, following the Mediterranean pattern, in Spain youths tend to delay departure from parental home until marriage, using precisely this period to save up resources in order to have a safer transition to independence. In contrast, in the U.S., as in other Western European countries, young people settle for an independent life earlier as they reach maturity, which would contribute to explain the larger vulnerability of the young households in this country. Further, our results indicate that the type of living arrangement highly conditions the chances of being poor when income and wealth are taken into account. In fact, we find that for every definition of the poor, single and lone parent households are the most exposed to poverty in every age

\footnotetext{
${ }^{22}$ The results in Tables 3 and 4 correspond to the case in which net worth is used to measure household wealth, the annuity from wealth is computed assuming a 5 percent interest rate, $Z_{Y}$ is set equal to 50 percent of the median annual household equivalent income, and the wealth poverty threshold is equal to $Z_{Y} / 4$. Importantly, results not presented here available upon request, suggest that the conclusions do not modify when net worth is replaced by non-housing wealth and alternative combinations of interest rates and poverty lines are considered.

${ }^{23}$ Notice that this exercise does not constitute an attempt to provide a casual model for income and asset-poverty. Instead, this model is thought to serve simply as a statistical description of the association between the poverty status and households' characteristics, such as the sex, age, educational level, and labour status of the head, as well as other variables regarding living arrangements.
} 


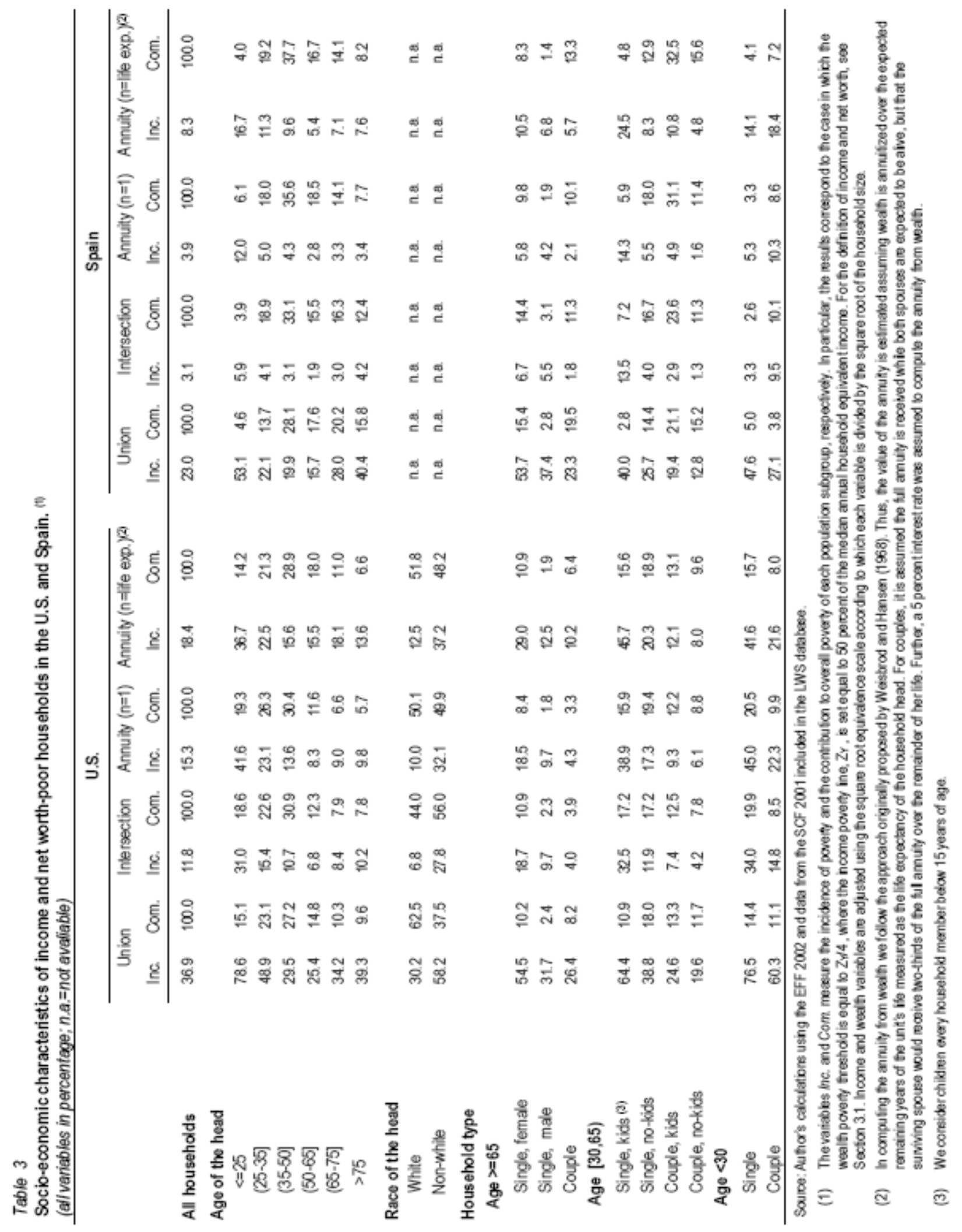


Table 4

Logit regression on the probability of income and net-worth poverty in Spain and the U.S. (1) (standard errors in parenthesis)

\begin{tabular}{|c|c|c|c|c|c|c|c|c|}
\hline & \multicolumn{4}{|c|}{ U.S. } & \multicolumn{4}{|c|}{ Spain } \\
\hline & Union & Intersection & $\begin{array}{c}\text { Annuity } \\
(\mathrm{t}=1)\end{array}$ & $\begin{array}{c}\text { Annuity } \\
(\mathrm{t}=\text { life exp })^{(1)}\end{array}$ & Union & Intersection & $\begin{array}{c}\text { Annuity } \\
(\mathrm{t}=1)\end{array}$ & $\begin{array}{c}\text { Annuity } \\
(t=\text { life exp })^{(1)}\end{array}$ \\
\hline Constant & $\begin{array}{l}-2.0^{* *} \\
(0.4)\end{array}$ & $\begin{array}{c}-4.8^{\star *} \\
(0.4)\end{array}$ & $\begin{array}{c}-3.8^{* *} \\
(0.4)\end{array}$ & $\begin{array}{l}-4.2^{* *} \\
(0.4)\end{array}$ & $\begin{array}{l}-0.8^{*} \\
(0.4)\end{array}$ & $\begin{array}{c}-3.7^{* *} \\
(0.9)\end{array}$ & $\begin{array}{c}-4.0^{* *} \\
(0.8)\end{array}$ & $\begin{array}{l}-2.5^{* *} \\
(0.6)\end{array}$ \\
\hline \multicolumn{9}{|c|}{ Age, sex, and race of the head } \\
\hline$<=25$ & $\begin{array}{l}2.4^{* *} \\
(0.2)\end{array}$ & $\begin{array}{l}1.5^{\star *} \\
(0.2)\end{array}$ & $\begin{array}{l}1.7^{\star *} \\
(0.2)\end{array}$ & $\begin{array}{l}1.4^{* *} \\
(0.2)\end{array}$ & $\begin{array}{l}1.6^{* *} \\
(0.4)\end{array}$ & $\begin{array}{c}0.8 \\
(0.8)\end{array}$ & $\begin{array}{l}1.4^{*} \\
(0.6)\end{array}$ & $\begin{array}{l}0.8^{*} \\
(0.5)\end{array}$ \\
\hline$(25-35]$ & $\begin{array}{l}1.0^{* *} \\
(0.1)\end{array}$ & $\begin{array}{l}0.4^{* *} \\
(0.2)\end{array}$ & $\begin{array}{l}0.7^{* *} \\
(0.1)\end{array}$ & $\begin{array}{l}0.6^{* *} \\
(0.2)\end{array}$ & $\begin{array}{c}0.2 \\
(0.2)\end{array}$ & $\begin{array}{c}0.5 \\
(0.4)\end{array}$ & $\begin{array}{c}0.4 \\
(0.3)\end{array}$ & $\begin{array}{l}0.4^{*} \\
(0.2)\end{array}$ \\
\hline$(50-65]$ & $\begin{array}{l}-0.3^{* *} \\
(0.1)\end{array}$ & $\begin{array}{l}-0.6^{* *} \\
(0.2)\end{array}$ & $\begin{array}{l}-0.7^{* *} \\
(0.2)\end{array}$ & $\begin{array}{c}0.0 \\
(0.2)\end{array}$ & $\begin{array}{l}-0.5^{* *} \\
(0.2)\end{array}$ & $\begin{array}{l}-0.9^{*} \\
(0.4)\end{array}$ & $\begin{array}{l}-0.5 \\
(0.4)\end{array}$ & $\begin{array}{l}-0.7^{* *} \\
(0.2)\end{array}$ \\
\hline$(65-75]$ & $\begin{array}{l}-0.3 \\
(0.2)\end{array}$ & $\begin{array}{l}-0.5 \\
(0.3)\end{array}$ & $\begin{array}{l}-0.9^{* *} \\
(0.3)\end{array}$ & $\begin{array}{l}-0.1 \\
(0.3)\end{array}$ & $\begin{array}{l}-0.2 \\
(0.2)\end{array}$ & $\begin{array}{l}-1.0^{*} \\
(0.5)\end{array}$ & $\begin{array}{l}-0.8^{*} \\
(0.4)\end{array}$ & $\begin{array}{l}-0.8^{*} \\
(0.3)\end{array}$ \\
\hline$>75$ & $\begin{array}{l}-0.3 \\
(0.2)\end{array}$ & $\begin{array}{l}-0.5 \\
(0.3)\end{array}$ & $\begin{array}{l}-0.9^{* *} \\
(0.3)\end{array}$ & $\begin{array}{l}-0.7^{*} \\
(0.3)\end{array}$ & $\begin{array}{l}-0.1 \\
(0.2)\end{array}$ & $\begin{array}{l}-1.1^{*} \\
(0.5)\end{array}$ & $\begin{array}{l}-1.2^{*} \\
(0.5)\end{array}$ & $\begin{array}{c}-1.0^{* *} \\
(0.3)\end{array}$ \\
\hline Female & $\begin{array}{l}0.4^{* *} \\
(0.1)\end{array}$ & $\begin{array}{c}0.3 \\
(0.2)\end{array}$ & $\begin{array}{c}0.3 \\
(0.2)\end{array}$ & $\begin{array}{l}0.4^{* *} \\
(0.2)\end{array}$ & $\begin{array}{l}-0.3^{* *} \\
(0.1)\end{array}$ & $\begin{array}{l}-0.3 \\
(0.3)\end{array}$ & $\begin{array}{l}-0.4 \\
(0.3)\end{array}$ & $\begin{array}{l}-0.2 \\
(0.2)\end{array}$ \\
\hline Non white (2) & $\begin{array}{l}1.0^{* *} \\
(0.1)\end{array}$ & $\begin{array}{l}1.4^{* *} \\
(0.1)\end{array}$ & $\begin{array}{l}1.1^{* *} \\
(0.1)\end{array}$ & $\begin{array}{l}1.2^{* *} \\
(0.1)\end{array}$ & & & & \\
\hline \multicolumn{9}{|l|}{ Household type } \\
\hline Size & $\begin{array}{c}0.1 \\
(0.2)\end{array}$ & $\begin{array}{c}0.3 \\
(0.2)\end{array}$ & $\begin{array}{c}0.2 \\
(0.2)\end{array}$ & $\begin{array}{c}0.3 \\
(0.2)\end{array}$ & $\begin{array}{l}-0.8^{* *} \\
(0.2)\end{array}$ & $\begin{array}{l}-1.0^{* *} \\
(0.4)\end{array}$ & $\begin{array}{l}-0.5 \\
(0.4)\end{array}$ & $\begin{array}{l}-0.6^{*} \\
(0.3)\end{array}$ \\
\hline Size ${ }^{\wedge} 2$ & $\begin{array}{c}0.01 \\
(0.02)\end{array}$ & $\begin{array}{c}0.00 \\
(0.02)\end{array}$ & $\begin{array}{c}0.00 \\
(0.02)\end{array}$ & $\begin{array}{c}0.01 \\
(0.02)\end{array}$ & $\begin{array}{l}0.1^{* *} \\
(0.02)\end{array}$ & $\begin{array}{l}0.1^{* *} \\
(0.04)\end{array}$ & $\begin{array}{c}0.1^{*} \\
(0.04)\end{array}$ & $\begin{array}{l}0.1^{*} \\
(0.03)\end{array}$ \\
\hline Single & $\begin{array}{l}0.5^{\star *} \\
(0.2)\end{array}$ & $\begin{array}{l}1.3^{* *} \\
(0.3)\end{array}$ & $\begin{array}{l}1.1^{* *} \\
(0.2)\end{array}$ & $\begin{array}{l}1.0^{* *} \\
(0.2)\end{array}$ & $\begin{array}{c}0.3 \\
(0.2)\end{array}$ & $\begin{array}{c}0.3 \\
(0.6)\end{array}$ & $\begin{array}{c}0.8 \\
(0.5)\end{array}$ & $\begin{array}{c}0.2 \\
(0.4)\end{array}$ \\
\hline Lone parent & $\begin{array}{l}1.0^{* *} \\
(0.2)\end{array}$ & $\begin{array}{l}1.6^{* *} \\
(0.3)\end{array}$ & $\begin{array}{l}1.2^{* *} \\
(0.3)\end{array}$ & $\begin{array}{l}1.4^{* *} \\
(0.2)\end{array}$ & $\begin{array}{l}1.4^{* *} \\
(0.4)\end{array}$ & $\begin{array}{l}2.3^{* *} \\
(0.6)\end{array}$ & $\begin{array}{l}2.1^{* *} \\
(0.6)\end{array}$ & $\begin{array}{l}1.9^{* *} \\
(0.4)\end{array}$ \\
\hline Couple with kids ${ }^{(3)}$ & $\begin{array}{l}-0.2 \\
(0.2)\end{array}$ & $\begin{array}{c}0.3 \\
(0.3)\end{array}$ & $\begin{array}{l}-0.2 \\
(0.3)\end{array}$ & $\begin{array}{c}0.1 \\
(0.2)\end{array}$ & $\begin{array}{l}0.7^{\star \star} \\
(0.2)\end{array}$ & $\begin{array}{l}1.4^{* *} \\
(0.4)\end{array}$ & $\begin{array}{l}1.2^{* *} \\
(0.3)\end{array}$ & $\begin{array}{l}1.0^{* *} \\
(0.2)\end{array}$ \\
\hline \multicolumn{9}{|c|}{ Education and Labour status (4) } \\
\hline Low educated & $\begin{array}{c}2.3 \\
(1.5)\end{array}$ & $\begin{array}{l}2.2^{*} \\
(0.9)\end{array}$ & $\begin{array}{l}2.0^{*} \\
(0.9)\end{array}$ & $\begin{array}{c}1.1 \\
(1.0)\end{array}$ & $\begin{array}{l}0.9^{* *} \\
(0.1)\end{array}$ & $\begin{array}{l}1.2^{* *} \\
(0.3)\end{array}$ & $\begin{array}{l}1.1^{* *} \\
(0.3)\end{array}$ & $\begin{array}{l}1.0^{* *} \\
(0.2)\end{array}$ \\
\hline High educated & $\begin{array}{c}0.4 \\
(0.6)\end{array}$ & $\begin{array}{c}0.5 \\
(0.9)\end{array}$ & $\begin{array}{c}0.4 \\
(0.9)\end{array}$ & $\begin{array}{c}0.1 \\
(0.9)\end{array}$ & $\begin{array}{c}-0.5^{\star} \\
(0.2)\end{array}$ & $\begin{array}{l}-0.5 \\
(0.8)\end{array}$ & $\begin{array}{l}-0.5 \\
(0.6)\end{array}$ & $\begin{array}{c}-0.8^{*} \\
(0.4)\end{array}$ \\
\hline Unemployed & $\begin{array}{l}1.1^{* *} \\
(0.2)\end{array}$ & $\begin{array}{l}1.0^{\star *} \\
(0.3)\end{array}$ & $\begin{array}{l}1.1^{* *} \\
(0.2)\end{array}$ & $\begin{array}{l}1.3^{* *} \\
(0.3)\end{array}$ & $\begin{array}{l}1.5^{* *} \\
(0.2)\end{array}$ & $\begin{array}{l}1.9^{* *} \\
(0.4)\end{array}$ & $\begin{array}{l}1.3^{* *} \\
(0.4)\end{array}$ & $\begin{array}{l}1.4^{* *} \\
(0.3)\end{array}$ \\
\hline Retired & $\begin{array}{l}1.1^{* *} \\
(0.2)\end{array}$ & $\begin{array}{l}1.4^{* *} \\
(0.3)\end{array}$ & $\begin{array}{l}1.1^{* *} \\
(0.2)\end{array}$ & $\begin{array}{l}1.4^{* *} \\
(0.2)\end{array}$ & $\begin{array}{l}0.4^{*} \\
(0.2)\end{array}$ & $\begin{array}{l}1.2^{*} \\
(0.5)\end{array}$ & $\begin{array}{l}0.7^{*} \\
(0.4)\end{array}$ & $\begin{array}{c}0.4 \\
(0.3)\end{array}$ \\
\hline Other inactive & $\begin{array}{l}2.3^{* *} \\
(0.2)\end{array}$ & $\begin{array}{l}2.5^{\star *} \\
(0.2)\end{array}$ & $\begin{array}{l}2.2^{* *} \\
(0.2)\end{array}$ & $\begin{array}{l}2.9^{* *} \\
(0.2)\end{array}$ & $\begin{array}{l}1.4^{* *} \\
(0.2)\end{array}$ & $\begin{array}{l}2.2^{* *} \\
(0.4)\end{array}$ & $\begin{array}{l}1.5^{\star \star} \\
(0.4)\end{array}$ & $\begin{array}{l}1.1^{\text {** }} \\
(0.3)\end{array}$ \\
\hline Sample & 4,402 & 4,402 & 4,402 & 4,402 & 5,143 & 5,143 & 5,143 & 5,143 \\
\hline Pseudo-R² & 0.19 & 0.25 & 0.23 & 0.24 & 0.13 & 0.15 & 0.12 & 0.11 \\
\hline
\end{tabular}

Source: Author's calculations using EFF 2002 and data from the SCF 2001 included in the LWS database.

(1) For the definition of income and net worth, see Section 3.1. The dependent variable is an indicator variable that takes value 1 when the household is identified as poor in each approach. The results correspond to the case in which the wealth poverty threshold is equal to $Z_{\gamma} / 4$, where the income poverty line, $Z_{Y}$, is set equal to 50 percent of the median annual household equivalent income. The value of the annuity from wealth is estimated assuming a 5 percent interest rate. The reference household is a household with a white male head between 36 and 50 years who lives with his spouse and without children, and where the head is working, with a medium educational level. Significance at 5 and 1 percent level is indicated by * and ${ }^{* *}$, respectively. (2) This information is not available in the Spanish survey. (3) We consider children every household member below 15 years of age. (4) Educational levels are defined according to the International Standard Classification of Education designed by UNESCO described in the appendix. 
group. The income problems usually urge this type of families, as well as the difficulties with saving these families face due to the absence of consumption economies of scale, and the larger liquidity constraints (Jappelli, 1990) clearly contribute to explain the larger vulnerability of these groups. Thus, among those above 65 , single females living alone are more likely to be identified as poor, particularly when the union definition is adopted (54 and 53 percent in the U.S. and Spain, respectively). In the case of households whose head is aged between 30 and 65, lone parent households are by far the most vulnerable group, especially in the U.S., where the proportion of poor among this group ranges between 32 and 64 percent depending on the way poverty is measured. Finally, households headed by unemployed, retired, or other inactive individuals face a larger risk of poverty in both countries independently of the way poverty is defined.

\subsection{Overlapping analysis}

The results from the previous section suggest that the characterization of the poor slightly differs for the different multidimensional approaches to poverty that consider both income and wealth. However, an important question remains to know to what extent the various poverty definitions identify the same households as poor. The purpose of this section is to answer this question by looking at the degree of overlapping between the various multidimensional poverty indices. Table 5 presents various information about the frequency distribution of households by the number of poverty indices which identify them as poor. Our figures suggest that the proportion of households identified as poor by any poverty index is larger in the U.S. than in Spain. In fact, more than 37 of U.S. households are classified as poor according to at least one of the poverty indices, whereas in Spain this figure is below 25 percent. Interestingly, this difference may be attributed to the housing component of wealth. Thus, when the housing component of wealth is excluded, the share of households who are not identified as poor by any poverty definition is around 54 percent in both countries. Furthermore, the proportion of households defined as poor by more than one poverty index is significantly greater in the U.S. Indeed, almost 56 percent of the U.S. households who are defined as poor by some definition are classified as poor by more than one index, and about 30 percent are defined as poor by the four indices considered, whereas in the case of Spain these figures are about 30 and 10 percent, respectively.

Table 6 looks at the degree of overlapping between the different poverty indices for all possible binary combinations of these indices. In particular, for each pairwise combination three measures of overlapping are presented: first, $O_{1}$, measures the proportion of households that are defined as poor according to both definitions; second, in order to 
Table 5

Distribution of households by the number of poverty indices according to which they are defined as poor in the U.S. and Spain (1)

(all variables in percentage)

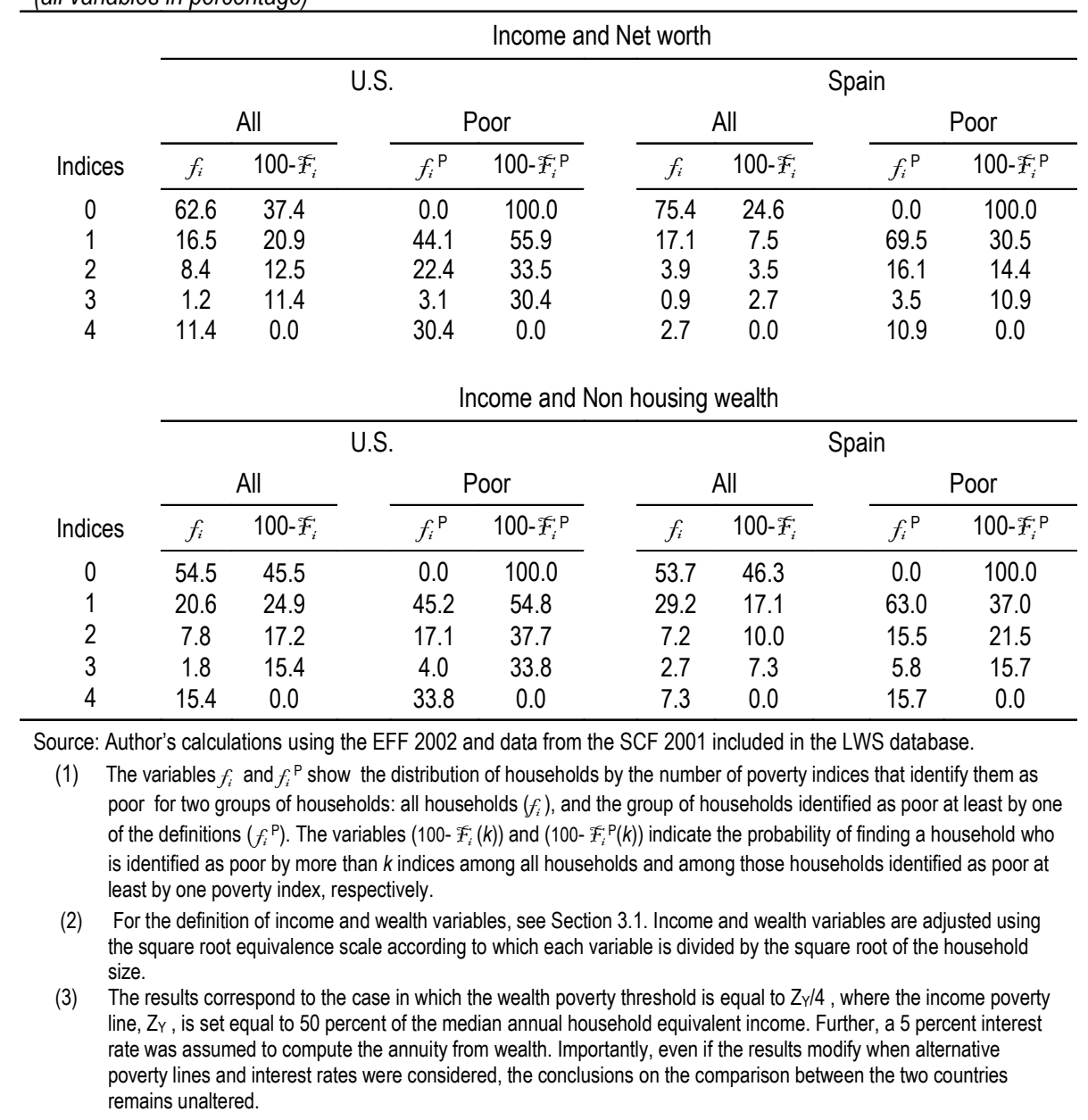

control for the differences in the incidence of poverty measured by the different poverty indices, $\mathrm{O}_{2}$, is defined as the share of households defined as poor by the two poverty definitions expressed as a percentage of the group of households classified as poor at least by one of the indices; thirdly, to control for the cross-country differences in the incidence of income and wealth poverty, the index $\mathrm{O}_{3}$ indicates the proportion of those households identified as poor by some of the two indices who are identified as poor by the two indices, assuming the incidence of income and wealth poverty is equal to 25 percent in both countries. Importantly, our results highlights a very low level of overlapping between the different poverty definitions. In fact, the estimates for $\mathrm{O}_{2}$ and $\mathrm{O}_{3}$ reveal that the rate of misclassification of the households identified as poor is above 50 percent for most of the pairwise comparisons. Thus, for instance, in the case of net worth, the level of overlapping 
between the union and the intersection approaches in the U.S. is around 30 percent, which implies that these methods identify the same households as poor in less than one third of the cases.

Table 6

Overlapping between poverty indices in the U.S. and Spain (all variables in percentage)

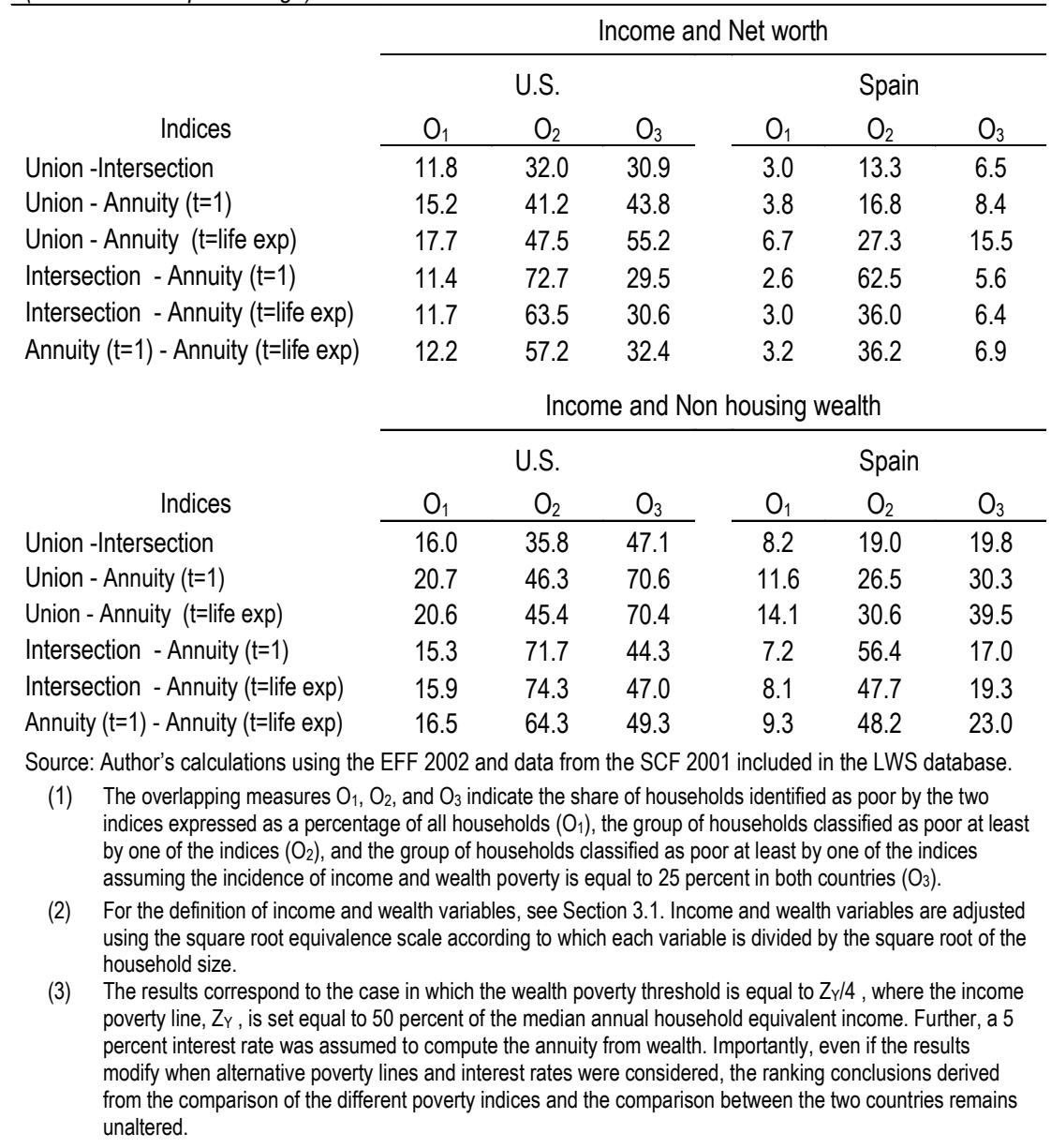

Interestingly, the comparison of the U.S. and Spain figures reveals important differences between the two countries. In particular, our results suggest the level of overlapping in the U.S. is significantly greater than in Spain in all the combinations of poverty indices whatever the measure of overlapping considered. In the case of income and net worth, for instance, the level of overlapping as measured by $\mathrm{O}_{2}$ or $\mathrm{O}_{3}$ in the U.S. is above 1.5 and 3 times that in Spain for all the pairwise combinations, respectively. How can be explained the larger level of misclassification observed in Spain? We point out the lower correlation between income and wealth found in Spain compared with the U.S. may contribute to 
explain this feature. ${ }^{24}$ Intuitively, the lower association between these two variables in Spain, implies that the probability of finding a low-income household with low (non low) wealth holdings in this country is lower (greater) than in a country where these variables are more closely correlated like in the U.S. The values of $\mathrm{O}_{2}$ for the comparison of the union and intersection poverty indices presented in Table 6 serve to illustrate this point. Thus, in the U.S., about 32 percent of those households who are either identified as income poor or net worth poor are deprived in the two dimensions, whereas in Spain this percentage is around 13 percent. This means that in Spain, of those households classified as poor in some of the two dimensions about 87 percent are deprived in only one dimension, whereas in the U.S. this proportion is about 17 percentage points lower. Consequently, given the way poverty is defined in the union, intersection, and annuity approaches, the larger concentration of population mass in regions characterized by low income and low wealth in the U.S. would account for the larger overlapping and the smaller misclassification we find in this country compared with Spain.

\section{Conclusions}

In this paper we examined the implications of the different multidimensional approaches to poverty based on income and wealth that have been proposed in the literature. We illustrated the differences implied by the different poverty definitions using data for two industrialized countries such as the U.S. and Spain. The analysis for these countries appears relevant for various reasons. First, the U.S. and Spain are both characterized by a welfare model typically catalogued as rather weak compared to that found in Nordic countries (Esping-Andersen et al., 2002). Consequently, the inclusion of wealth into the measurement of poverty in the case of these two countries would be especially relevant due to the greater importance of assets as a private insurance mechanism in countries with low social protection. Further, the comparison is interesting due to the differences in the demographic structure observed in these two countries (Bover 2010, Reher 1998). Differences in the household formation process and living arrangements may influence the relationship between income and wealth holdings over the life cycle and therefore the structure of the poor when poverty is measured using income and wealth.

We study the effect of using different poverty definitions considering both income

\footnotetext{
${ }^{24}$ According to our figures presented in Section 3.2, in Spain, the coefficients of correlation between income and net worth and income and non-housing wealth are about 0.15 and 0.12 , respectively, whereas in the U.S. these figure are around 0. 5 and 0.49 .
} 
and wealth on the incidence and characterization of the poor. Concretely, we compare two multidimensional approaches to poverty that differ in relevant methodological issues that may have important implications on the structure of poverty. The first approach, suggested by Radner and Vaughan (1987) and Wolff (1990) look at income and wealth independently so that shortfalls in one of the dimensions can not be compensated with excess in the other dimension. Alternatively, the second approach proposed by Weisbrod and Hansen (1968), allows for the possibility of compensation between meagre and nonmeagre attribute quantities as income and wealth are integrated into a single index of welfare.

Our results indicates that the incidence of poverty in the U.S. and Spain varies importantly depending on the way poverty is defined. More concretely, we find that the union and the intersection definitions of poverty provide an upper and a lower bound on the number of households who are identified as poor, while the poverty figures estimated using the annuity criteria lying between the two extremes. Moreover, the size of poverty in the U.S. is larger than is Spain regardless of the particular poverty approach and the combination of poverty lines considered. In particular, the most striking difference between these two countries is found for the intersection definition as the proportion of households identified as poor under this criterion in the U.S. is between 1.5 and 6 times that in Spain. Remarkably, despite the variation in the number of poor, we find the poverty profile is very similar for the different poverty approaches. Thus, households headed by individuals under 35 are the most exposed to poverty, with the risk of poverty clearly decreasing with the age of head regardless of the definition of the poor used. Regarding the question on the extent to which different poverty definitions identify as poor the same households, our figures for Spain and the U.S. suggest a high level of misclassification among the poverty definitions: for most of the pairwise comparisons of poverty indices the proportion of poor households that are misclassified is above 50 percent. Between Spain and the U.S., we find that the rate of overlapping between poverty indices is significantly larger in the later. We argue the larger correlation between income and wealth at the bottom of the distribution in the U.S. may contribute to explain this result. 


\section{Appendix}

\subsection{Information in the EFF and the SCF}

\begin{tabular}{|c|c|c|c|c|}
\hline & \multicolumn{2}{|c|}{ EFF 2002} & \multicolumn{2}{|c|}{ SCF 2001} \\
\hline & Ownership & Value & Ownership & Value \\
\hline \multicolumn{5}{|l|}{ Real assets } \\
\hline Principal residence & A & A & A & A \\
\hline Other real state properties & A & $A$ & $A$ & $A$ \\
\hline Vehicles & $A$ & $A$ & A & $A$ \\
\hline Business equities & A & $A$ & $A$ & $A$ \\
\hline Durables and Collectibles ${ }^{(1)}$ & A & A & A & A \\
\hline \multicolumn{5}{|l|}{ Financial assets } \\
\hline Saving and deposits & A & $A$ & $A$ & $A$ \\
\hline Fixed income securities & A & A & $A$ & A \\
\hline Mutual funds & A & $A$ & A & $A$ \\
\hline Shares & A & A & A & A \\
\hline Private pension schemes & A & A & A & $A$ \\
\hline Life Insurance & A & A & A & A \\
\hline Other financial assets & A & A & A & A \\
\hline \multicolumn{5}{|l|}{ Debts } \\
\hline Principal residence & A & A & A & $A$ \\
\hline Other real state properties & A & A & A & A \\
\hline Vehicles and educational loans & A & $A$ & A & $A$ \\
\hline Other debts & A & A & A & A \\
\hline
\end{tabular}

Source: Author's calculations using EFF 2002 and data from the SCF 2001 included in the LWS database.

(1) This category includes gold, silver, works of art, jewelry, antiques, stamps collections, and other miscellaneous assets in the household.

\subsection{Education Coding}

To group households according the educational level of the head we follow the International Standard Classification of Education (ISCED) provided by the UNESCO:

- LOW includes no education, pre-primary, primary, lower secondary, compulsory and initial vocational education.

- MEDIUM includes upper secondary general education, basic vocational education, and post-secondary education.

- HIGH includes specialized vocational education, university/college education and (post)-doctorate and equivalent degrees. 


\section{References}

[1] Becker S., Bentolila S., Fernandes A., Ichino A. (2005) "Youth emancipation and perceived job insecurity of parents and children". Discussion paper 5339, Centre for Economic Policy Research.

[2] Bourguignon, F. and Chakravarty, S.R. (2003). "The Measurement of Multidimensional Poverty". Journal of Economic Inequality, Vol. 1, No 1, pp. 25-49.

[3] Bover, O. (2004). "The Spanish Survey of Household Finances (EFF): Description and Methods of the 2002 Wave". Occasional paper No.0409, Banco de España.

[4] Bover, O. (2010). "Wealth Inequality and Household Structure: U.S. vs. Spain". Review of Income and Wealth, Vol. 56 (2), 259-290.

[5] Budria, S., Díaz-Jiménez, J., Quadrini, V. and Ríos-Rull, J. V. (2002). "Updated Facts on the U.S. Distributions of Earnings, Income and Wealth". Federal Reserve Bank of Minneapolis Quarterly Review, Summer 26 (3), 2-35.

[6] Buhmann, B., Rainwater, L., Schmauss, G., Smeeding, T. (1988). "Equivalence Scales, Well-Being, Inequality, and Poverty: Sensitivity Estimates across Ten Countries Using the Luxembourg Income Study (LIS) Database," Review of Income and Wealth, Vol. 34, No. 2, pp. 115-42.

[7] Caner, A., and Wolff, E. N. (2004). "Asset Poverty in the United States, 1984-1999: Evidence from the Panel Study of Income Dinamics". Review of Income and Wealth, Series 50, Vol. 4, pp. 493-518.

[8] Chakravarty, S. R., and Silber, J. (2007). "The Axiomatic Approach to Multidimensional Poverty Measurement", in N. Kakwani and J. Silber, Quantitative Approaches to Multidimensional Poverty Measurement, London, Palgrave-Macmillan.

[9] Chakravarty, S. R., Deutsch, J., and Silber, J. (2005). "On The Watts Multidimensional Poverty Index", paper presented at the International Conference on The Many Dimensions of Poverty, International Poverty Centre, Brasilia, August 2005.

[10] Davies, J. B. and Shorrocks A. F. (2000). "The Distribution of Wealth", in A. B. Atkinson and F. Bourguignon (eds.) Handbook of Income Distribution, Vol. 1, pp. 605-75. Amsterdam: North-Holland. 
[11] Esping-Andersen, G., Gallie, D., Hemerijck, A., and Myles, J. (2002). Why We Need a New Welfare State. Oxford, UK: Oxford University Press.

[12] Fernández-Cordón, J. A. (1997). "Youth Residential Independence and Autonomy: a Comparative Study". Journal of Family Issues, Vol. 18, No. 6, pp. 576-607.

[13] Haveman R. and Wolff, E. (2005). "The Concept and Measurement of Asset Poverty: Levels, Trends and Composition for the U.S., 1983-2001" Journal of Economic Inequality, Vol. 2, No. 2, pp. 145-169.

[14] Hubbard, R. G., Skinner, J., and Zeldes, P. (1995). "Precautionary Saving and Social Insurance". The Journal of Political Economy, Vol. 103, No. 2, pp. 360-399.

[15] Jäntti, M., Sierminska, E., and Smeeding, T. (2008). "The Joint Distribution of Household Income and Wealth: Evidence from the Luxembourg Wealth Study". OECD Social Employment and Migration Working Papers, No. 65, OECD Publishing.

[16] Jappelli, T. (1990). "Who is Credit Constrained in the U.S. Economy?. Quarterly Journal of Economics, Vol. 105, No. 1, pp. 219-34.

[17] Jarvis, S. and Jenkins, S. P. (1998). "Low Income Dynamics in 1990s Britain". Fiscal Studies, Vol. 18, No. 2, pp. 123-142.

[18] Jesuit, D. and Smeeding T. (2002). "Poverty and Income Distribution". Working Paper No. 293, Luxembourg Income Study.

[19] Kennickell, A. (1998). Multiple Imputation in the Survey of Consumer Finances. Working paper SCF group, Federal Reserve Board.

[20] Kennickell, A. (2000). Wealth Measurement in the Survey of Consumer Finances: Methodology and Directions for Future Research. Working paper SCF group, Federal Reserve Board.

[21] Kennickell, A. (2008). "The Role of Over-Sampling of the Wealthy in the Survey of Consumer Finances". Irving Fisher Committee Bulletin No. 28, August, 2008.

[22] National Center for Health Statistics. National Vital Statistics Reports Vol. 51, No. 3. Available at http://www.cdc.gov/nchs/data/nvsr/nvsr51/nvsr51_05.pdf 
[23] Notten, G. and Neubourg de, C. (2007). "Relative or absolute poverty in the US and EU? The battle of the rates". MGSoG Working Paper, 2007/001, Maastricht Graduate School of Governance, Maastricht University, Maastricht.

[24] Radner, D. and Vaughan, D. (1987). "Wealth, Income, and the Economic Status of Aged Households" in E. Wolff (eds.), International Comparisons of the Distribution of Household Wealth.

[25] Reher, D. S. (1998). "Family ties in Western Europe: persistent contrasts". Population and Development Review, Vol. 24, No. 2, pp. 203-234.

[26] Short, K. and Ruggles, P. (2006). "Experimental Measures of Poverty and Net Worth: 1996". Journal of Income Distribution, Special issue on assets and poverty, pp. 8-21.

[27] Shorrocks, A. F., (1978). "The Measurement of Mobility". Econometrica, Vol. 46, pp. 1013-1024.

[28] Sierminska, E. and Smeeding T. M. (2005). "Measurement Issues: Equivalence Scales, Accounting Framework, and Reference Unit". Paper presented at the Luxembourg Wealth Study Workshop, Perugia, 27-29 January 2005.

[29] Spanish Statistical Office (Instituto Nacional de Estadistica, INE). Figures on life expectancy for the Spanish population 1991-2007. Available at http://www.ine.es/jaxi/tabla.do?type=pcaxis\&path=/t20/p319a/1991-2007/ $/ 10 / \&$ file $=01001 . p x$

[30] Van den Bosch, K. (1998). "Poverty and Assets in Belgium" Review of Income and Wealth, Vol. 44, No. 2, pages 215-228.

[31] Weisbrod, B. and Hansen W.L. (1968). "An Income-Net Worth Approach to Measuring Economic Welfare”. American Economic Review, Vol. 58, pp. 1315-1329.

[32] Wolff, E. N. (1990). "Wealth holdings and Poverty Status in the U.S.". Review of Income and Wealth, Vol. 30, No. 2, pp. 143-165.

[33] Wolff, E. N. (1998). "Recent Trends in the Size Distribution of Household Wealth". Journal of Economic Perspectives, 12, 131-150.

[34] Zagorsky, J. L.(2006). "Measuring Poverty Using both Income and Wealth". Journal of Income Distribution, Special issue on assets and poverty, pp. 22-40. 